\title{
Effects of different dwarfing interstocks on key enzyme activities and the expression of genes related to malic acid metabolism in Red Fuji apples
}

\author{
J. Shi, F.F. Li, H. Ma, Z.Y. Li and J.Z. Xu \\ Horticultural Department of Hebei Agricultural University, Baoding, Hebei Province, \\ China \\ Corresponding author: J.Z. Xu \\ E-mail: sjuanmah2418@126.com \\ Genet. Mol. Res. 14 (4): 17673-17683 (2015) \\ Received August 26, 2015 \\ Accepted October 3, 2015 \\ Published December 21, 2015 \\ DOI http://dx.doi.org/10.4238/2015.December.21.40
}

\begin{abstract}
In this experiment, the test materials were 'Red Fuji' apple trees grafted onto three interstocks (No. 53, No. 111, and No. 236), which were chosen from SH40 seeding interstocks. The content of malic acid, the enzyme activities, and the expression of genes related to malic acid metabolism were determined during fruit development. The results showed that malic acid content in the ripe fruit on interstock No. 53 was higher than that in the interstock No. 111 fruit. The malate dehydrogenase (NAD-MDH) activity in apples on interstock No. 53 was highest on Day 30, Day 100, and Day 160 after bloom, and the malic enzyme (NADP-ME) activity in apples on interstock No. 111 was higher than in the interstock No. 53 fruit from Day 70 to Day 100 after bloom. The relative expression of NAD-MDH genes in interstock No. 53 fruit was higher than in No. 236 fruit on Day 100 after bloom, but the relative expression of NADP-ME in No. 236 interstock fruit was lower than in No. 53 fruit. The relative expression of NAD-MDH genes in No. 53 interstock fruit was highest on Day 160 after bloom. This might have been the main reason for the difference in the accumulation of malic
\end{abstract}


acid in the ripe apples. There was a positive correlation between the relative expression of phosphoenolpyruvate carboxylase (PEPC) and the malic acid content of the fruit, and the content of malic acid in the apples was affected by the PEPC activity during the early developmental stage.

Key word: Red Fuji; Dwarfing interstocks; Malic acid; NAD-MDH; Reverse transcription-PCR

\section{INTRODUCTION}

The types and content of organic acids influence the inherent quality of fruits. Malic acid is the major organic acid in apples. Apples are malic acid-dominant fruit (Chen et al., 2005) in which acid metabolism is regulated by various enzymes. Under catalysis by phosphoenolpyruvate carboxylase (PEPC) in the fruit cytoplasm, phosphoenolpyruvate (PEP) produced via the glycolytic pathway is converted into oxaloacetic acid (OAA). In the presence of malate dehydrogenase (NAD$\mathrm{MDH}), \mathrm{OAA}$ is turned into malic acid, which is decomposed by the catalytic effect of malic enzyme (NADP-ME) into pyruvic acid (Ruffner et al., 1984; Muñoz et al., 2001). PEPC, NADP-ME, and NAD-MDH are the key enzymes regulating malic acid synthesis and decomposition (Martinoia and Rentsch, 1994; Zhao et al., 2007; Wang et al., 2013).

In fact, acid metabolism and regulation in apples are very complex, and the acid content is jointly regulated by the relevant genes and enzymes. Molecular biology techniques have been applied to characterize the key enzymes of acid metabolism. Some researchers have measured the expression levels of PEPC and NADP-ME genes in apple cytoplasm in fruit belonging to high- and low-acid genotypes (Yao et al., 2009). Yao et al. (2011) cloned the full-length NAD-MDA gene into apples and tested its function. Or et al. (2000) found that the transcriptional levels of ME, NADP-MDH, and PEPC genes are crucial for the regulation of malic acid metabolism in grapes during the growth stages.

Environmental conditions and cultivation practice have a large impact on fruit quality (Thakur and Singh, 2012; Xu et al., 2012). Research shows that the organic acid content of apples is also influenced by stocks (Liu et al., 2007). However, the mechanism by which stocks affect the organic acid content of fruit is unknown. In this study, Red Fuji apple trees were grafted onto different dwarfing interstocks and were used as the test materials to determine malic acid content, metabolic enzyme activities, and the expression levels of the relevant genes during fruit growth. We have thereby provided a theoretical basis for ascertaining the mechanism by which interstocks affect the organic acid content of fruit.

\section{MATERIAL AND METHODS}

\section{Materials}

The test materials were from the Stock Experimental Garden of Baoding Comprehensive Experimental Station, which belongs to the National Modern Apple Industry Technical System. The 6-year-old Red Fuji apple trees were grafted with dwarfing interstocks (numbers 53, 111, and 236 were used). All three types of interstock were the offspring of SH40. Studies have shown that their dwarfing effect and early-fruiting property are superior those of SH40. Using Malusmicromalus as the rootstock, Tianhong No. 2 was grafted at a spacing of $0.75 \mathrm{~m} \times 3.0 \mathrm{~m}$. Consistent cultivation and management measures were adopted. Single-tree plot experiments were carried out with five 
replicates. Trees showing consistent bloom stage were chosen for artificial pollination. Five fruits were collected from each tree, peeled, and deseeded. The pulp was preserved in liquid nitrogen $\left(-196^{\circ} \mathrm{C}\right)$ and placed in an ultra-cold storage freezer $\left(-74^{\circ} \mathrm{C}\right)$.

\section{Extraction of organic acids}

Gao's method (Gao et al., 2007) was adopted with modifications. Frozen pulp (5 g) was ground in anhydrous alcohol, transferred to a $50-\mathrm{mL}$ conical bottle, and ultrasonically extracted for $10 \mathrm{~min}$. Suction filtration was performed to extract the solution, and the solution was evaporated on a rotary evaporator. Next, $15 \mathrm{~mL} 12 \%$ sulfuric acid in methanol was added to dissolve the product, followed by transfer to a $50-\mathrm{mL}$ volumetric flask. This was carried out three times. After heating in a water bath at $80^{\circ} \mathrm{C}$ for $1 \mathrm{~h}$, the solution was titrated with ultrapure water and centrifuged at $4000 \mathrm{~g}$ for $5 \mathrm{~min}$. The supernatant was collected and placed in a triangular bottle with a stopper. A pipette was used to transfer the solution described above $(30 \mathrm{~mL})$, and extraction was carried out three times with dichloromethane (10 $\mathrm{mL}$ each time). The extraction liquor was added with an appropriate amount of anhydrous sodium sulfate and passed through a $0.22-\mu \mathrm{m}$ milipore filter.

\section{Quantification of organic acids}

Gas chromatography-mass spectrometry (GC-MS) was performed for quantification of the organic acids in the apples. The GC-MS conditions were as follows.

The GC was conducted using a 6890GC/5973MSD instrument (Agilent, CA, USA). An HP-5MS column $(30 \mathrm{~m} \times 250 \mu \mathrm{m} \times 0.25 \mu \mathrm{m})$ was used with an inlet temperature of $280^{\circ} \mathrm{C}$. The programmed temperature regimen comprised: a column temperature of $70^{\circ} \mathrm{C}(0.5 \mathrm{~min})$; a temperature increase rate of $10^{\circ} \mathrm{C} / \mathrm{min}$ to $280^{\circ} \mathrm{C}$ (maintained for $1 \mathrm{~min}$ ); then an increase at $5^{\circ} \mathrm{C} / \mathrm{min}$ to $290^{\circ} \mathrm{C}$ (maintained for $15 \mathrm{~min}$ ). We used helium as a carrier; the flow rate was $1 \mathrm{~mL} / \mathrm{min}$; the loading amount was $1 \mu \mathrm{L}$; and the system was operated in non-split mode.

The MS conditions were: electron ionization (EI); electron energy, $70 \mathrm{eV}$; ion source temperature, $230^{\circ} \mathrm{C}$; quadrupole temperature, $150^{\circ} \mathrm{C}$; electron multiplier voltage, $1.89 \mathrm{kV}$; scanning range, 35-500 U; and full-scan mode.

\section{Quantification of malic acid}

Malic acid content was determined by GC. The GC was conducted using an Agilent 7890A Gas Chromatograph (USA). Derivatives detection was by GC. We used FID apparatus, a G4513A automatic liquid sampler (Agilent, USA), an Hp-5 capillary column (5\%-phenyl-methyl polysiloxane, $30 \mathrm{~m} \times 25 \mu \mathrm{m} \times 0.1 \mu \mathrm{m}$ ) with an inlet temperature of $230^{\circ} \mathrm{C}$ and a monitor temperature of $250^{\circ} \mathrm{C}$. We used high purity $\mathrm{N}_{2}$ as carrier, a flow rate of $45 \mathrm{~mL} / \mathrm{min}$, an $\mathrm{N}_{2}$ flow rate of $40 \mathrm{~mL} / \mathrm{min}$, a column pressure of $12.00 \mathrm{psi}$, a loading amount of $1 \mu \mathrm{L}$, and a split ratio of $30: 1$. The programmed temperature regimen comprised: an initial temperature of $60^{\circ} \mathrm{C}$ maintained for $2 \mathrm{~min}$; an increase to $120^{\circ} \mathrm{C}$ at a rate of $8^{\circ} \mathrm{C} / \mathrm{min}$; an increase to $160^{\circ} \mathrm{C}$ at $20^{\circ} \mathrm{C} / \mathrm{min}$ (maintained for $4 \mathrm{~min}$ ); and finally an increase to $250^{\circ} \mathrm{C}$ at $40^{\circ} \mathrm{C} / \mathrm{min}$ (maintained for $10 \mathrm{~min}$ ).

Plotting of the standard curve: $0.9983 \mathrm{~g}$ malic acid was accurately weighed and placed in a 5-mL volumetric flask; methanol was added to the graduation mark. Aliquots of the above solution $(10,100,250,500$, and $1000 \mu \mathrm{L})$ were transferred to a $50-\mathrm{mL}$ volumetric flask, and $15 \mathrm{~mL} 12 \%$ sulfuric acid in methanol was added for derivation and extraction. Linear regression analysis was 
carried out according to peak area of malic acid $(Y)$ and corresponding mass $(X)$. The standard curve was plotted as $y=18.648 x-9.347$, with coefficient of correlation $R=0.99900$.

\section{Determination of enzyme activities}

\section{Preparation of enzyme solutions}

Hirai's method (Hirai and Ueno, 1977) was adopted with slightly modifications. Pulp ( $3 \mathrm{~g}$ ) was ground with $3 \mathrm{~mL}$ grinding fluid in an ice bath $\left(4^{\circ} \mathrm{C}\right)$ and centrifuged at $4000 \mathrm{~g}$ for $20 \mathrm{~min}$. The supernatant liquor was collected and diluted to $5 \mathrm{~mL}$, and $2.5 \mathrm{~mL}$ was taken and centrifuged at $4^{\circ} \mathrm{C}$ and $15,000 \mathrm{~g}$ for $15 \mathrm{~min}$. The precipitate was dissolved with extraction solution to $2.5 \mathrm{~mL}$ to obtain NAD-IDH enzyme solution. Then, $2.5 \mathrm{~mL}$ extraction solution was added to obtain NAD-MDH and NAD-ME enzyme solution. All procedures were completed at $0-4^{\circ} \mathrm{C}$. The grinding buffer comprised $0.2 \mathrm{M}$ Tris- $\mathrm{HCl}, \mathrm{pH}$ 8.2; $0.6 \mathrm{M}$ sucrose; and $10 \mathrm{mM}$ arabo-ascorbic acid. The extraction buffer comprised: $0.2 \mathrm{M}$ Tris- $\mathrm{HCl}, \mathrm{pH} 8.2 ; 10 \mathrm{mM}$ arabo-ascorbic acid; and 0.1\% Triton X-100.

\section{Determination of enzyme activity}

The methods used by Hirai (Hirai and Ueno, 1977) and Luo (Luo et al., 2003) were referred to. The 3-mL reaction system for the detection of each enzyme was as follows. For NADP$\mathrm{ME}$, the system comprised $300 \mu \mathrm{L} 0.8 \mathrm{M}$ Tris- $\mathrm{HCl}, \mathrm{pH} 7.4 ; 150 \mu \mathrm{L} 4 \mathrm{mM}$ NADP; $150 \mu \mathrm{L} 4 \mathrm{mM}$ $\mathrm{MnSO}_{4} ; 300 \mu \mathrm{L}$ ultrapure water; $500 \mu \mathrm{L}$ enzyme solution; $1600 \mu \mathrm{L} 4 \mathrm{mM}$ malic acid; and a detection wavelength of $340 \mathrm{~nm}$. For NAD-MDH, the system comprised: $300 \mu \mathrm{L} 0.8 \mathrm{M}$ Tris- HCl, $\mathrm{pH} 8.2 ; 150$ $\mu \mathrm{L} 0.01 \mathrm{M}$ glutathione (GSH); $150 \mu \mathrm{L} 3 \mathrm{mM} \mathrm{NADH} ; 150 \mu \mathrm{L} 0.2 \mathrm{M} \mathrm{KHCO}_{3} ; 150 \mu \mathrm{L} 0.04 \mathrm{M} \mathrm{MgCl}_{2}$; $500 \mu \mathrm{L}$ enzyme solution; $1600 \mu \mathrm{L} 4 \mathrm{mM}$ OAA; and a detection wavelength of $340 \mathrm{~nm}$. For PEPC, the system comprised: $300 \mu \mathrm{L} 0.8 \mathrm{M}$ Tris-HCl, pH 8.5; $150 \mu \mathrm{L} 0.01 \mathrm{M} \mathrm{GSH} ; 150 \mu \mathrm{L} 3 \mathrm{mM}$ NADH; $150 \mu \mathrm{L} 0.04 \mathrm{MMgCl}_{2} ; 150 \mu \mathrm{L} 0.2 \mathrm{MKHCO}_{3} ; 500 \mu \mathrm{L}$ enzyme solution; $1600 \mu \mathrm{L} 4 \mathrm{mM}$ PEP; and a detection wavelength of $340 \mathrm{~nm}$. A UV-2450 ultraviolet spectrophotometer was used to measure the absorbance. The scan was performed for $3 \mathrm{~min}$ at a unit of $5 \mathrm{~s}$ to record the changes of absorbance, with three replicates. One enzyme unit was defined as 0.01 absorbance change per min and expressed as $\mathrm{U} \cdot \mathrm{g}^{-1} \cdot \mathrm{FW} \cdot \mathrm{min}^{-1}$.

\section{Reverse transcription quantitative polymerase chain reaction (RT-qPCR) detec- tion of enzymes related to malic acid metabolism}

\section{Total RNA extraction and reverse transcription}

Total RNA extraction and RT-qPCR detection were performed for fruit samples at Day 30, Day 70, and Day 100 after bloom, using two replicates for each sample. Total RNA was extracted using an Easy-spin Plus Plant RNA Kit (Nanjing Zhongding Biotechnology Co., Ltd.) in accordance with the manufacturer instructions. The extracted total RNA was then detected by agarose gel electrophoresis and ultraviolet spectrophotometry. Genomic DNA (gDNA) was removed before reverse transcription through the following procedures: $4 \mathrm{X}$ gDNA wiper Mix $(2 \mu \mathrm{L})$, template RNA (500 ng), and RNase-free double-distilled $\mathrm{H}_{2} \mathrm{O}$ were added to an RNase-free centrifuge tube to 10 $\mu \mathrm{L}$, with gentle blowing using a pipette. The reaction proceeded at $42^{\circ} \mathrm{C}$ for $2 \mathrm{~min}$. Then, $5 \mathrm{X}$ qRT Super Mix II $(2 \mu \mathrm{L})$ and the reaction solution $(8 \mu \mathrm{L})$ from the first step were added. RNA was reverse 
transcribed into complementary DNA (cDNA) under the following conditions: $25^{\circ} \mathrm{C}$ for 10 min, $42^{\circ} \mathrm{C}$ for $30 \mathrm{~min}$, and $85^{\circ} \mathrm{C}$ for $5 \mathrm{~min}$.

\section{$R T-q P C R$}

A quantitative fluorescence PCR was carried out according to the manufacturer instructions using $2 X$ SYBR Green qPCR Mix. The reaction system $(20 \mu \mathrm{L})$ comprised $2 X$ qPCR Master Mix $(10 \mu \mathrm{L}) ; 10 \mu \mathrm{M}$ forward primer $(0.4 \mu \mathrm{L}) ; 10 \mu \mathrm{M}$ reverse primer $(0.4 \mu \mathrm{L})$; template (cDNA) $(2$ $\mu \mathrm{L}$ ); and double-distilled $\mathrm{H}_{2} \mathrm{O}$. The conditions for the quantitative fluorescence PCR were as follows. For the amplification curve: $94^{\circ} \mathrm{C}$ for $30 \mathrm{~s} ; 94^{\circ} \mathrm{C}$ for $10 \mathrm{~s} ; 60^{\circ} \mathrm{C}$ for $12 \mathrm{~s} ; 72^{\circ} \mathrm{C}$ for $30 \mathrm{~s}$, for a total of 45 cycles; and a final extension at $72^{\circ} \mathrm{C}$. For the dissolution curve: $95^{\circ} \mathrm{C}$ for $0 \mathrm{~s} ; 65^{\circ} \mathrm{C}$ for $15 \mathrm{~s} ; 95^{\circ} \mathrm{C}$ for $0 \mathrm{~s}$; and continuous detection. The primers for the quantitative fluorescence PCR were designed according to the gene sequences with $\beta$-actin as internal control (Apple Research Team of the School of Horticulture and Agricultural at the University of Hebei Province). The primer sequences are listed in Table 1. The expression levels of three genes, NAD-MDH, NADP-ME, and PEPC, were detected.

\begin{tabular}{llr}
\multicolumn{2}{c}{ Table 1. Primer sequences for reverse transcription polymerase chain reaction (RT-PCR). } \\
\hline Gene & Sequence $\left(5\right.$ ' to $\left.3^{\prime}\right)$ & GenBank accession No. \\
\hline NAD-MDH-F & GTCAAGATGGAGTTGGTGGAG & DQ221207 \\
NAD-MDH-R & TGGTGTTTGCGGGTTAG & DQ280492 \\
NADP-ME-F & GGATTCGGTCTGGGTTT & EU315246 \\
NADP-ME-R & GTAGTTTCGGTAGATGGGAC \\
PEPC-F & CCTCCAAATGAACCCTACC & \\
PEPC-R & CACTGGCTAACAACTGACGA & \\
NF & GGATTTGCTGGTGATGATGCT & \\
NR & AGTTGCTCACTATGCCGTGCT & \\
\hline
\end{tabular}

\section{Statistical analysis}

Data sorting and plotting were conducted using Excel 2003. Significance tests and correlation analyses were carried out using DPS and SPSS 13.0 softwares, respectively.

\section{RESULTS}

\section{Quantification of organic acids in apples}

After methylation, the pulp was analyzed by GC-MS and the total ion chromatograms of the methylated organic acids were obtained. By searching the NIST98 database, 12 methylated organic acids were identified. Thus, the samples detected contained 2-butenedioic acid, 4-oxopentanoic acid, malic acid, 2-butynedioic acid, 3-acetoxy-3-hydroxypropionic acid, carbamic acid, methoxy-butanedioic acid, 2-methyl-pentanoic acid, citric acid, 4-hydroxy-3-methoxy-benzeneacetic acid, 2,3-dihydro-3-benzofurancarboxylic acid, and hexadecanoic acid. The content of each methylated organic acid was determined by using the area normalization method (Table 2). It was found that the dimethyl ester of malic acid had the largest relative content, which was $78.17 \%$, indicating that malic acid was the predominant organic acid in Red Fuji apples. 
Table 2. Constituents and contents of the methylated organic acids from Red Fuji apples.

\begin{tabular}{lclr}
\hline Peak No. & Retention time & Compounds & Relative contents (\%) \\
\hline 1 & 6.027 & 2-Butenedioic acid-, dimethyl ester & 0.53 \\
2 & 6.597 & Pentanoic acid, 4-oxo-, methyl ester & 0.63 \\
3 & 7.587 & Malic acid, dimethyl ester & 78.17 \\
4 & 8.015 & 2-Butynedioic acid, dimethyl ester & 13.64 \\
5 & 8.56 & 3-Acetoxy-3-hydroxypropionic acid, methyl ester & 0.61 \\
6 & 9.55 & Carbamic acid, methyl ester & 1.01 \\
7 & 10.431 & Butanedioic acid, methoxy-, dimethyl ester & 0.69 \\
8 & 11.571 & Pentanoic acid, 2-methyl-, methyl ester & 0.17 \\
9 & 12.251 & Citric acid, trimethyl ester & 1.22 \\
10 & 13.132 & Benzeneacetic acid, 4-hydroxy-3-methoxy-, methyl ester & 0.24 \\
11 & 16.94 & 3-Benzofurancarboxylic acid, 2,3-dihydro-, methyl ester & 2.89 \\
12 & 17.544 & Hexadecanoic acid, methyl ester & 0.20 \\
\hline
\end{tabular}

\section{Changes of malic acid content in Red Fuji apples on different dwarfing interstocks}

The overall change trend of malic acid content in apples on the three different interstocks was similar to that of titratable acid content (Figure 1). On Day 20 after bloom, the malic acid content began to rise, reaching a peak on Day 30. After that, the malic acid content declined until maturity. On Day 20 after bloom, the malic acid content in the apples on the No. 53 interstock was significantly higher than in apples on the No. 111 interstock. On Day 40 after bloom, the malic acid content in the apples on the No. 236 interstock was much lower than in apples on the other two interstocks. On Day 160 after bloom, the malic acid content in the apples on the No. 53 interstock was considerably higher than that in the apples on the No. 111 interstock $(P<0.05)$; the malic acid content of the apples in the two interstocks was 5.08 and $4.47 \mathrm{mg} / \mathrm{g}$, respectively.

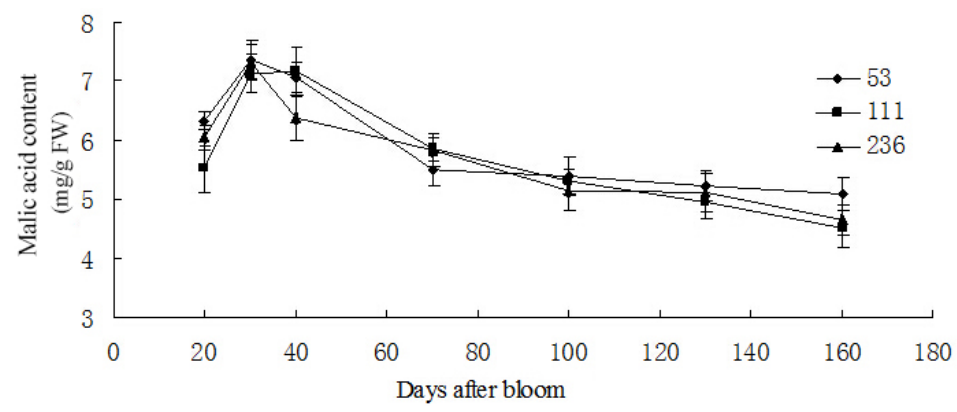

Figure 1. Changes of malic acid content in Red Fuji apples on the different interstocks.

\section{Changes in NAD-MDH activity and gene expression}

NAD-MDH activities in the apples on the three interstocks all reached the lowest level on Day 20 after bloom (Figure 2). The NAD-MDH activities showed an increasing trend on Day 20 after bloom and reached a peak on Day 30. At this time, the NAD-MDH activity in the apples on the No. 53 interstock was significantly higher than in the apples on the No. 111 interstock, and the two NAD-MDH activities were $163.50 \mathrm{U} \cdot \mathrm{g}^{-1} \mathrm{FW} \cdot \mathrm{min}^{-1}$ and $134.43 \mathrm{U} \cdot \mathrm{g}^{-1} \mathrm{FW} \cdot \mathrm{min}^{-1}$, respectively. On Day 100 and Day 160 after bloom, the NAD-MDH activities in all apples declined; the highest NADMDH activity was found in apples on the No. 53 interstock, and the lowest in apples on the No. 111 interstock; the difference was statistically significant. 


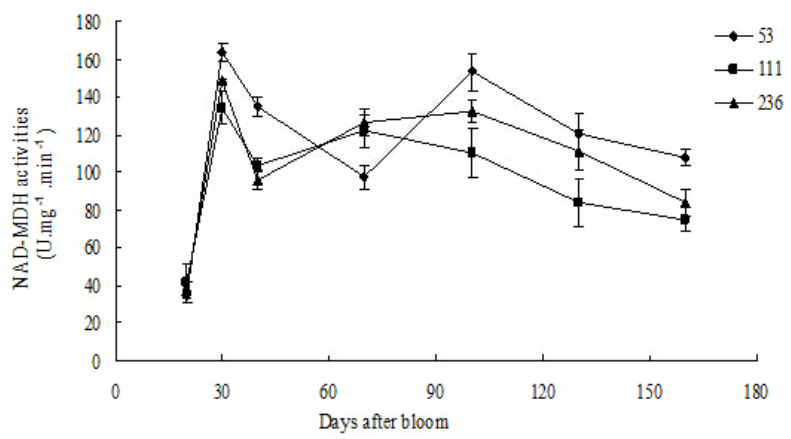

Figure 2. Changes of NAD-MDH activity in Red Fuji apples on the different interstocks.

The results of real-time fluorescence quantitative PCR detection for the NAD-MDH gene in the apples are shown in Figure 3. The relative expression of the NAD-MDH gene in apples on the No. 111 interstock on Day 30 after bloom was considerably higher than in the apples on the other interstocks. On Day 100 after bloom, the relative expression levels of the NAD-MDH gene in apples on the No. 53 interstock and the No. 236 interstock were significantly higher than in the apples on the No. 111 interstock, reaching 4.77 and 4.07 times the latter, respectively. On Day 160 after bloom, the relative expression of the NAD-MDH gene in the apples on the No. 53 interstock was significantly higher than in apples on the other interstocks. The relative expression of the NAD-MDH gene in apples on the No. 53 interstock was 1.84 and 4.45 times that for the No. 111 interstock and the No. 236 interstock, respectively.

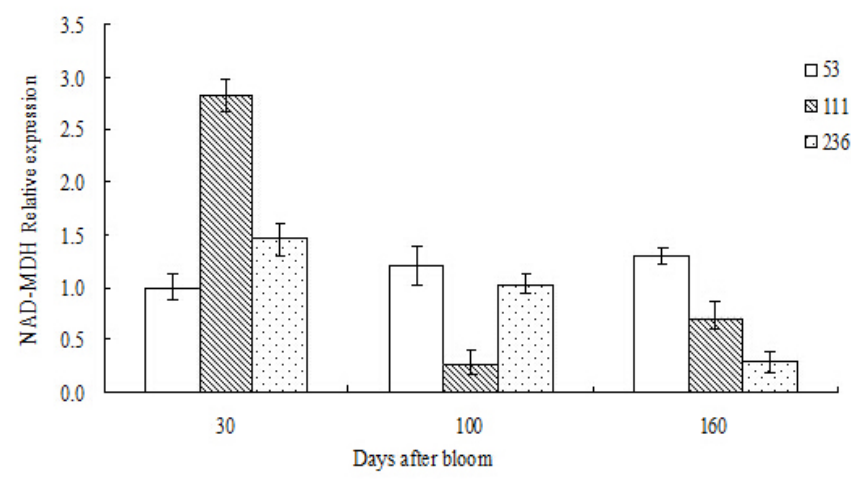

Figure 3. Relative expression of NAD-NDH in Red Fuji apples on the different interstocks.

\section{Changes in PEPC activity and gene expression}

On all three interstocks, PEPC activities initially increased and then decreased along with fruit growth (Figure 4). From Day 20 after bloom, PEPC activity levels in the fruits began to rise. PEPC activity levels in apples on the No. 111 interstock and the No. 236 interstock reached a peak on Day 40 after bloom. At this time, the PEPC activity in the apples on the No. 236 interstock was significantly higher than in the other interstocks. PEPC activity in apples on the No. 53 interstock reached a peak on Day 30, which was much higher than in the No. 111 interstock apples, and then declined. From Day 100 to maturity, PEPC activity in apples on the No. 53 interstock decreased 
slowly; on Day 130, PEPC activity in apples on the No. 53 interstock was significantly higher than in the other interstocks. However, no significant differences were observed among other treatments.

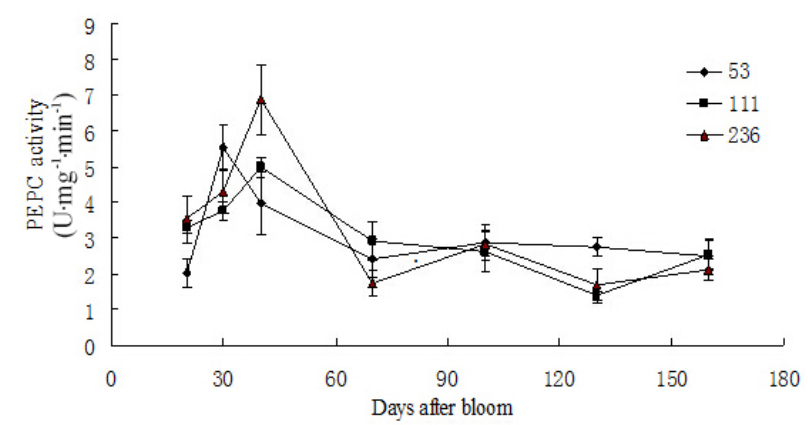

Figure 4. Change of PEPC activity in Red Fuji apples on the different interstocks.

The results of real-time fluorescence quantitative PCR for the PEPC gene are shown in Figure 5. On Day 30 after bloom, the relative expression of the PEPC gene in the apples on the No. 236 interstock was significantly higher than in the other interstocks. On Day 100 after bloom, the relative expression of the PEPC gene in the apples on the No. 236 interstock was much higher than in the No. 111 interstock apples; the relative expression of the PEPC gene in the apples on the No. 53 interstock was not significantly different from that in the No. 111 and No. 236 interstock apples. On Day 160, the apples on the No. 53 interstock showed an obvious increase in relative expression of the PEPC gene compared with the other interstocks. The relative expression of the PEPC gene in apples on the No. 53 interstock was 4.49 times and 1.22 times that in the No. 111 and No. 236 interstock apples, respectively; the relative expression of the PEPC gene in apples on the No. 236 interstock was 3.67 times that in the No. 111 interstock apples; the difference was statistically significant.

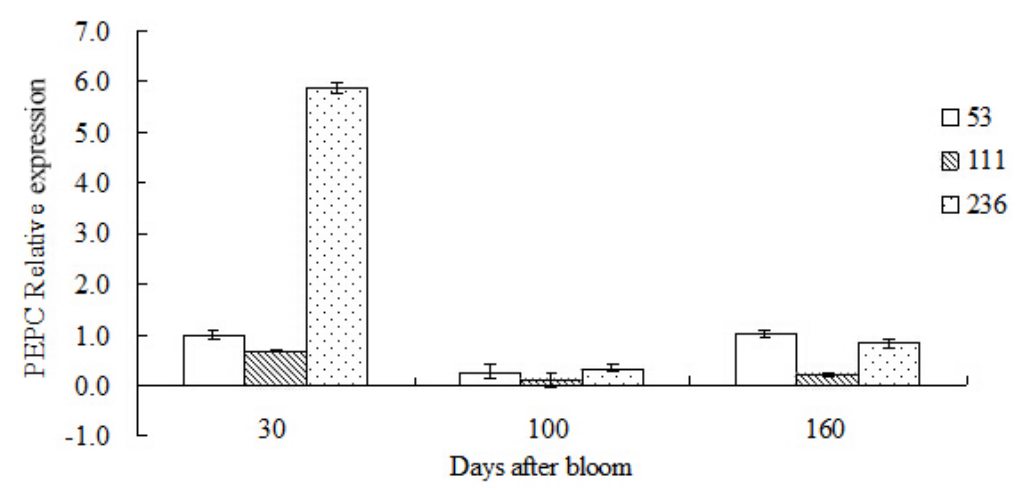

Figure 5. Relative expression of PEPC in Red Fuji apples on the different interstocks.

\section{Changes in NADP-ME activity and gene expression}

NADP-ME activity levels in the apples on the three interstocks generally showed an increasing trend over time (Figure 6). NADP-ME activities in all three interstocks were relatively 
low from Day 20 to Day 30 after bloom. Following Day 40 after bloom, NADP-ME activity levels in apples on the No. 53 and No. 236 interstocks began to increase; NADP-ME activity in the No. 53 interstock apples was higher than in the No. 236 interstock apples, with significant differences on Day 40, Day 70, Day 100, and Day 130. NADP-ME activity in apples on the No. 111 interstock began to rise after Day 40 and reached a peak on Day 100. At this time, NADP-ME activity in the apples on the No. 111 interstock was considerably higher than in the other interstock apples.

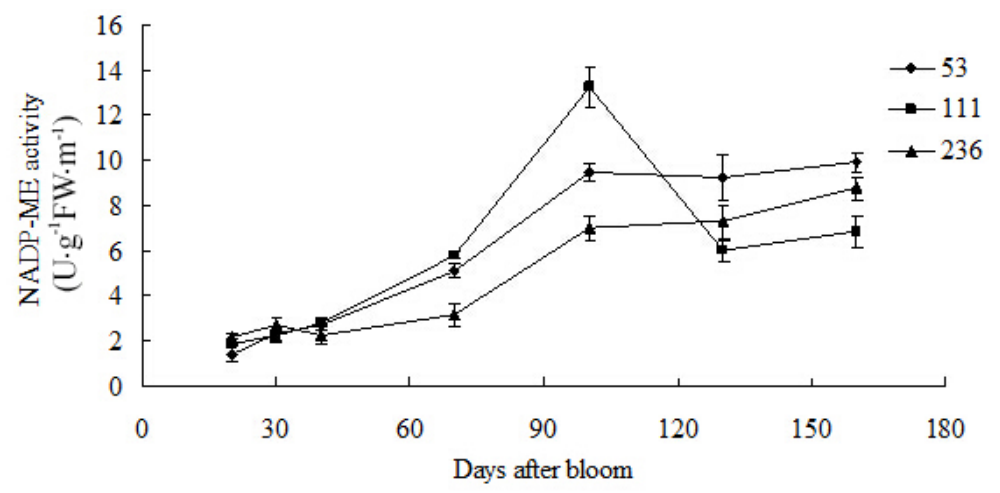

Figure 6. Changes of NADP-ME activity in Red Fuji apples on the different interstocks.

The results of real-time fluorescence quantitative PCR for the NADP-ME gene are shown in Figure 7. It can be seen that on Day 30 after bloom, the relative expression of the NADP-ME gene in the apples on the No. 236 interstock was significantly higher than in the No. 53 and No. 111 interstock apples, being 4.55 and 2.62 times the latter two, respectively; the difference in relative expression of the NADP-ME gene between the No. 53 and No. 111 interstock apples was not significant. On Day 100 after bloom, the relative expression of the NADP-ME gene in the apples on the No. 53 interstock was much higher than in those on the other interstocks; the relative expression of the NADP-ME gene in the apples on the No. 53 interstock was 2.83 and 4.69 times that in the No. 111 and No. 236 interstock apples, respectively. On Day 160 after bloom, the relative expression of the NADP-ME gene in the apples on the No. 236 interstock was highest, and there were significant differences among all the treatment groups.

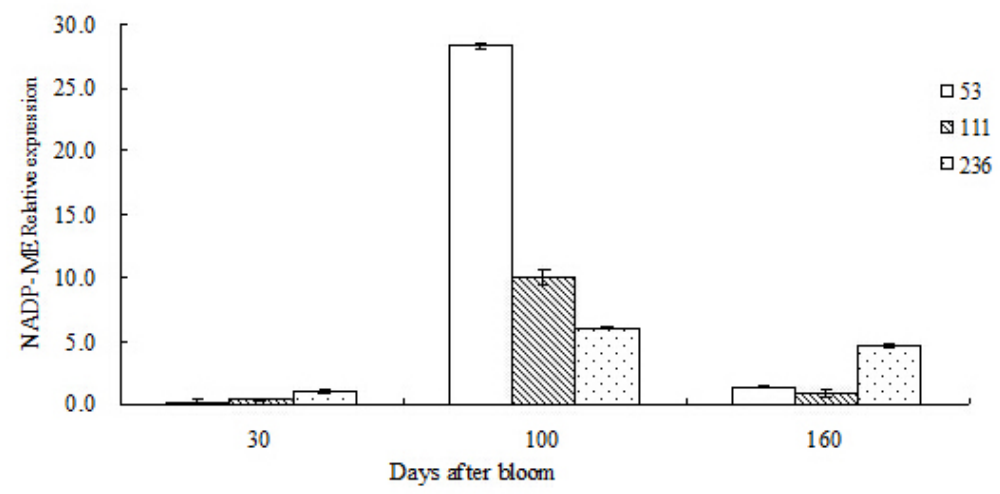

Figure 7. Relative expression of MADP-ME in Red Fuji apples on the different interstocks. 


\section{DISCUSSION}

Stocks influence organic acid content in fruits to a certain extent. In this study, the malic acid content in Red Fuji apples on different dwarfing interstocks varied significantly. After maturity, the malic acid content in the apples on the No. 53 interstock was much higher than in the No. 111 interstock apples. It has been discovered that a pair of major genes related to the low-acid trait in fruits has a regulatory effect on the key enzymes of malic acid metabolism. Therefore, the relationship between malic acid accumulation and the expression of key enzymes can be analyzed by detecting the level of transcription, the protein content, and the enzyme activity (Maliepaard et al., 1998; Yao et al., 2008a). MDH gene expression is associated with malic acid accumulation in fruits at all stages (Yao et al., 2008b). NAD-MDH is the key enzyme of malic acid production in fruits. lannetta et al. (2004) found that NAD-MDH activity was greatly enhanced with increasing malic acid content as strawberries mature. Our study suggested that the NAD-MDH activity in the apples on the No. 53 interstock was highest on Day 30 after bloom, corresponding to the highest malic acid content; moreover, the difference was significant compared with the No. 111 interstock apples. Before maturity, NAD-MDH activity levels in all the treatment groups declined gradually. On Day 100 and Day 160 after bloom, the NAD-MDH activity in the apples on the No. 53 interstock was markedly higher than in the No. 111 interstock apples; in addition, the relative expression of the NAD-MDH gene in the former was much higher than in the latter. Zhao et al. (2007) divided the changes in organic acids in nectarines into two stages, namely, organic acid synthesis and organic acid decomposition. Our research indicated that at the later growth stages of apples, the significant difference in NAD-MDH activity and the relative expression of the NAD-MDH gene in alternative treatment groups was the main reason for the difference in malic acid content in mature Red Fuji apples in the different treatment groups.

Luo et al. (2003) believed that PEPC activity in citrus fruits had an impact on organic acid metabolism. Wang et al. (2013) studied Cerasushumilis fruits with different acid content, and found that the enhanced PEPC activity at the later growth stages promoted malic acid accumulation. It was also found that the PEPC gene was expressed differentially in fruits of high- and low-acid genotypes (Yao et al., 2009). In our experiment, PEPC activity in the No. 53 interstock treatment was highest on Day 30 after bloom, corresponding to the highest malic acid content. Although the relative expression of the PEPC gene in apples on the No. 53 interstock was not the highest, it was significantly higher than in the No. 111 interstock apples. On Day 160, the relative expression of the PEPC gene in apples on the No. 53 interstock was much higher than in the No. 111 and No. 236 interstock apples, respectively. Thus, the relative expression of the PEPC gene in the different treatment groups was positively correlated with malic acid content. In the early growth stages, PEPC promoted malic acid accumulation in the apples. As the apples matured, PEPC activities influenced malic acid accumulation in the different treatment groups.

The existing studies on grapes (Ruffner et al., 1984), pears (Sha, 2012), and nectarines (Wang et al., 2013) all demonstrated that NADP-ME activity was negatively correlated with malic acid content. Dong et al. (2013) cloned two NAD-ME genes from Fuji apples, namely MdNADME1 and MdNAD-ME2, which were proved to play different roles at different growth stages. In the present study, on Day 30 after bloom, the relative expression of the NADP-ME gene in apples on the No. 236 interstock was significantly higher than in No. 53 interstock apples, and the enzyme activity of the former was also higher than in the latter. From Day 70 to Day 100 after bloom, NADPME activity in the apples on the No. 111 interstock was much higher than in the No. 53 interstock apples, and the malic acid content was also higher. This may be the critical stage of NADP-ME 
action, resulting in much higher malic acid content in ripe fruits on the No. 53 interstock compared with the No. 111 interstock.

\section{Conflicts of interest}

The authors declare no conflict of interest.

\section{REFERENCES}

Chen FX, Liu XH and Chen LS (2005). Advances in research on organic acid metabolism in fruits. J. Fruit Sci. 22: 526-531.

Chen MX, Zhao CK, Chen XS, Hao HJ, et al. (2009). Relationship between accumulation of organic acid and organic acidmetabolizing enzymes during apricot fruit development. J. Fruit Sci. 26: 471-474.

Dong QL, Yu XM, Liu DD, Wang HR, et al. (2013).Cloning of NAD-malic enzymes and their expression analysis during tissues and fruit development of apple. Acta Hort. Sin. 40: 739-748.

Gao Y, Zhu XL and Yang J (2007). Analysis of organic acids in Actinidiachinensis by capillary gas chromatography. Food Sci. 28: 273-274.

Hirai M and Ueno I (1977). Development of citrus fruits: fruit development and enzymatic changes in juice vesicle tissue. Plant and Cell Physiol. 18: 791-799.

lannetta PP, Escobar NM, Ross HA, Souleyre EJ, et al. (2004). Identification, cloning and expression analysis of strawberry (Fragaria $\mathrm{x}$ ananassa) mitochondrial citrate synthase and mitochondrial malate dehydrogenase. Physiol. Plant 121: 15-26.

Liu GR, Chen HJ, Xu JZ, Ma BK, et al. (2007). The effect of different dwarfing interstocks on 'Red Fuji' apple fruit quality. J. Agr. Univ. Hebei 30: 24-26.

Luo AC, Yang XH, Deng YY, Wang YY, et al. (2003). Organic acid concentrations and the relative enzymatic changes during the development of citrus fruits. Sci. Agr. Sin. 36: 941-944.

Maliepaard C, Alston FH, van Arkel G, Brown LM, et al. (1998). Aligning male and female linkage maps of apple (Maluspumila Mill.) using multi-allelic markers. Theor. Appl. Genet. 97: 60-73.

Martinoia E and Rentsch D (1994). Malate compartmentation-responses to a complex metabolism. Annual Review of Plant Physiol. Plant Mol. Biol. 45: 447-467.

Muñoz T, Escribano Ml and Merodio C (2001). Phosphoenolpyruvate carboxylase from cherimoya fruit: properties, kinetics and effects of high $\mathrm{CO}(2)$. Phytochemistry 58: 1007-1013.

Or E, Baybik J, Sadka A and Saks Y (2000). Isolation of mitochondrial malate dehydrogenase and phosphoenolpyruvate carboxylase cDNA clones from grape berries and analysis of their expression pattern throughout berry development. J. Plant Physiol. 157: 527-534.

Ruffner HP, Possner D, Brem S and Rast DM (1984). The physiological role of malic enzyme in grape ripening. Planta 160: 444-448.

Sha SF (2012). Pear organic acid components, content changes and genetic identification. Ph.D. Dissertation, Nanjing Agricultural University, Nanjing.

Thakur A and Singh Z (2012). Responses of 'Spring Bright' and 'Summer Bright' nectarines to deficit irrigation: fruit growth and concentration of sugars and organic acids. Sci. Hort. 135: 112-119.

Wang PF, Xue XF and Mu XP (2013). Scientia Agricultura Sinica. 46: 4101-4109.

Xiu Z, Guo JY and Wang YZ (2014). Journal of Plant Nutrition and Fertilizer 20: 414-420.

Xu XJ, Li QY, Song XH, Shen QR, et al. (2012). Dynamic regulation of nitrogen and organic acid metabolism of cherry tomato fruit as affected by different nitrogen forms. Pedosphere 22: 67-78.

Yao YX, Hao YJ, Li M, Pang ML, et al. (2008a). Gene cloning expression and enzyme activity assay of a cytosolic malate dehydrogenase from apple fruits. Front. Agric. China 2: 307-313.

Yao YX, Zhai H, Zhao LL, Yi K, et al. (2008b). Analysis of apple fruit acid/low-acid trait by SSR markers. Front. Agric. China 2: 463-466.

Yao YX, Li M, Liu Z, You CX, et al. (2009). Molecular cloning of three malic acid related genes MdPEPC, MdVHA-A, MdcyME and their expression analysis in apple fruits. Sci. Hort. 122: 404-408.

Yao YX, Li M, Zhai H, You CX, et al. (2011). Isolation and characterization of an apple cytosolic malate dehydrogenase gene reveal its function in malate synthesis. J. Plant Physiol. 168: 474-480.

Zhao YH, Li XL, Jiang ZS, Wang CJ, et al. (2007). Organic acid metabolism in nectarine fruit development under protected cultivation. Chin. J. Eco-Agriculture 15: 87-89. 